\title{
ある庁舎の屋根と外壁の経年変化の状況と 維持保全工事に関する記録
}

\author{
正会員橋 本 正五*
}

緒言 元来建物の維持保全は屋根と外壁の雨風に対す る考慮を主とする。てれは庁舎が事変戦争占領等の影響 をうけて，外壁仕上未完成のまま使用され，後から防空 上やむをえず屋上に耐弾層が設けられ，しかも充分な維 持保全が行われず，自然現象により老化していった状況 を調査研究し，復旧していった記録である。技術上の難 問題が多かったが，この大蔵省庁舎だけでなく，今なお 耐弹層のある文部省, 人事院, 警視庁の各庁舎, 耐弾層 はないが外装未完成の農林省庁舎等があり，一般に参考 になることと思われるので報告する。

\section{1 概 要}

（1）建物 SRC 構造，地下 1 地上 5 階一部 3,4 階 建, 軒高 $25 \mathrm{~m}$, 建面積 $12,500 \mathrm{~m}^{2}$, 延 $56,000 \mathrm{~m}^{2}$, 屋根 は全面に亘り耐弾首があり，外壁はタイル貼予定のまま コンクリート打放しとなっていた。

（2）庁舎の経歴 - 昭 9.6.15 工費 8,000 千円を 以て着工・昭 11.12 .20 事変による資材難のため工事 中止の方釬決定, 鉄部防錆のためコンクリート工事のみ 続行, 乙の完了は 13 年頃 - 昭 14.10.10 工事再開, 主として内装工事実施 - 昭 15.6.8 仮竣功, 外装の 大部々内装の一部は未完・昭 15.6.20 木造旧庁合焼 失し, 移転使用開始, 補足工事を併行 - 昭 18.7.31 竣功, 外装タイル貼末完・昭 19. 末戦争激化のため屋 根全面に R C 造耐弾層設置 - 昭 20.9.15 敗戦により 米軍の全面接収を受け，職員は急扰立退き分散・昭 21 . 4.20 分散執務中の職員は泍く四谷第 3 小学校汇集結, 庁舎は兵合 PX 等に使用され「フアイナンスビル」と称 さる・昭 30.12.17 接収解除返還さる。当時空室多く, 各所とも荒れはてていた。・昭 31.3 .31 兵舎浴室PX 等の事務室への復旧工事等完了, 移転復㷌 - 昭 35.2 . $12 \sim 3.30$ 工費 1,750 千円を以て庁舎西北隅の一部而 弾層の試験的撤去 — 昭 36. 3. 9 8.31 工費 47,751 千円を以。て大部の耐弾層撤去, $3 \sim 4$ 階の屋根耐弾層 残置 —昭 36.6.14 11.15 工費 18,200 千円を以て撤 去あとに新防水首設置 昭 37. 7. 4 38.11.30 工費 151,569 千円を以てタイル貼外装と空枠補修を完了

（3）調査の概要・昭 30.12 当初, 未完成の外装を 完成させたいといった立場から調査にかかった。当時室

\section{* 大蔵省営繥専門官}

(昭和 40 年 2 月 4 日本稿受理, 討論期限 40 年 9 月末日)
内外への雨漏, 外壁コンクリートの亀裂, 剥離がみられ た。・昭 31.4 建築研究機関に調查を依頼していた 処，次の回答をえた。「外壁コンクリートの中性化によ り鉄部が発錆膨張し，コンクリートに刍裂のみられる処 がある。放置すれば剥落事故が続発し，建物の耐久力を 損し，価值が低下し，改修工事が大規模 となる」一昭 32.9 雨漏, 剥落やまず，困惑していたが，遇々昇降 機修理に際してリフト内から屋根防水層に向けて，はつ り工事を行った処，晴天にも拘らず水が噴出，数日間滴 下して屋根面下に滞水首のあることが確認された。爾後 長期間予算建設保守各担当機関の間で，外装之耐弾層撤 去の必要性につき工事の難易とも関連して討議が続い た。・昭 33.4 外壁の調査を大規模に実施・昭 34.2 屋根汃建物内外への漏水状況を詳細汇調查・昭 34.5 耐弾層設置工事の，当時の担当者と本問題につき意見交 換・昭 34.6 他庁舎につき耐弾層と外壁の状況を調查， 保守担当者之意見交換の昭 34.7 関係各機関の間で 「外装タイル貼前に耐弾首を撤去して漏水の原因を除去 し，荷重の軽减を図ることが保全及び施工上から必要で ある」ととに意見一致・昭 36.5 各機関が集り，外装 工事の程度及び方法につき協議・昭 37.7 空枠窝蝕状 況の調查実施

\section{2 建物外壁の調査}

(1) 概要, 調査目的, 要領, 昭 13 頃 1 階密台以下 石貼完了し，上部はスクラッチタイル貼予定でコンクリ 一ト打のまま放置された。炤 33.4 乙の打放面の状況， 中性化進度，鉄材の発錆状況等を調查して外壁補修と夕 イル貼の要否を検討する目的で, 外壁内外面, 東西南北 中庭面, 高低各面, 普通面打継面各別にそれぞれ数ヶ所 づつ外面観察，かきとり観察及び中性化試験を実施し た。

（2）外面観察 鉄筋被覆は 15 50 耗, 施工の不備 によってそれ以下の処もあり表面は粗い。空䞤りや被覆 の薄い処にコンクリート亀裂, 剥離がみられる。打継面 は全面にわたって鉄錆流出のしみがある。

（3）加きり観察 打継面及び重裂や空隙個所の鉄 材には必ず浮錆があり，鉄筋断面減少，鉄骨浮錆等まで みられる。コンクリートに異状のない処にも鉄筋酸化が みられ，打継面直上部にコンクリート村料分離が多い。

（4）コンクリート中性化進度の測定 内外壁斫孔を 


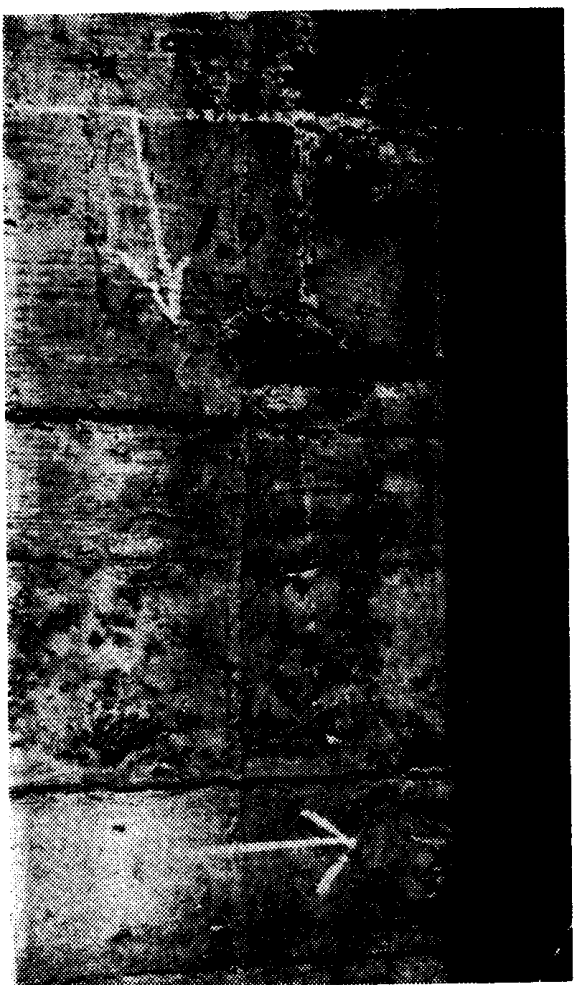

1 鉄筋治いに剥離・龟裂
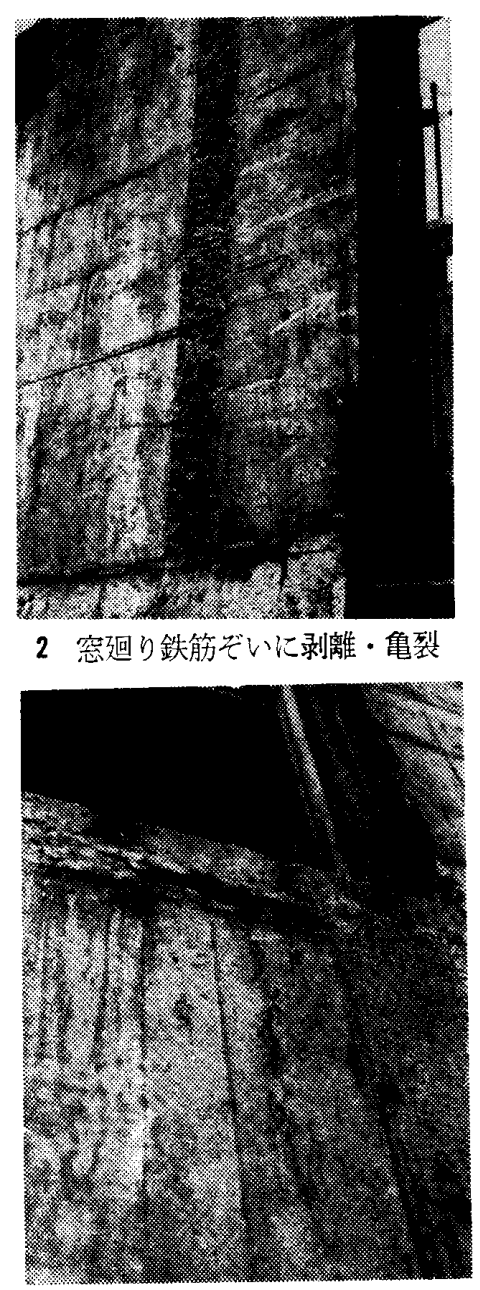

2 空迴り鉄筋ぞいに剥離・亀裂

3 空迴り鉄筋沿いに亀裂

フェノールフタレン指 示薬で測定した。中性 化状沅は第 1 図のよう 溇型的である。

（5）中性化進度と 測定位置との関係 建 物周过は東面北面がひ らけ，東方には交通の 激しい大通り及び 4 キ 口距てて海をひかえ， 南面は㹨い道路をはさ み隣接徍物，西面は高 地部が迫っている。

(6) 調查結果 乙 の建物の老柯化は外壁 に存在露呈している施 工上の欠点から著しく 進んでおり，打継面， 空迴り，鉄筋被覆の特 に薄い処等の中性化が 早く，鉄材の浮錆臌張 によるコンクリート亀 裂と相俟って更に促進 されている。また部分 摘出調䍒にも拘らず鉄骨浮錆の甚しい処が 3 力所もみら れ，建物の正当な寿命を保つたもには不良個処の補修を 行った上で外装を施し，一刻も早く外壁を保護すべきだ と思われる。特記事項としては

・経年 20 年のコンクリート中性化進度を浜田博士の

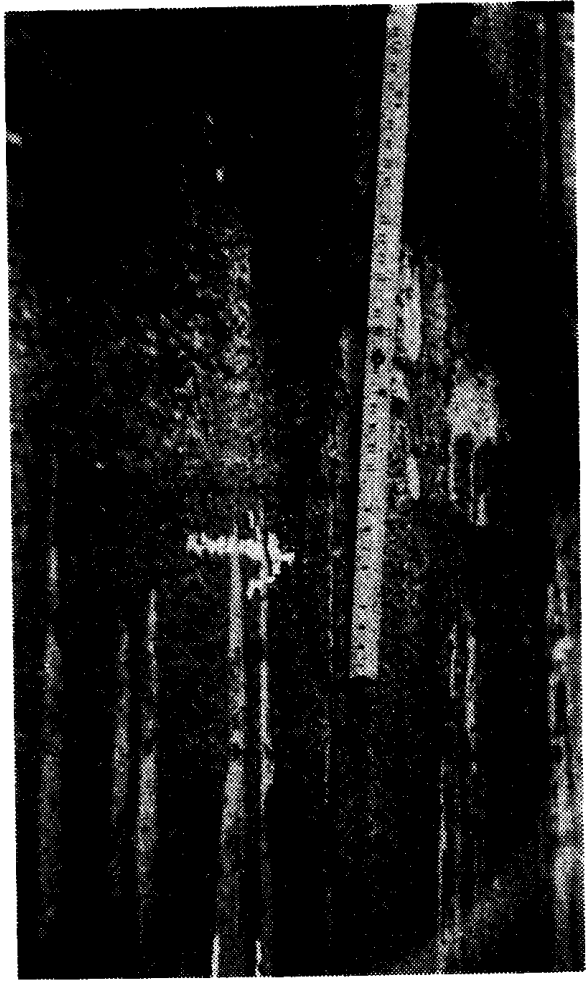

4 鉄筋にそい亀裂

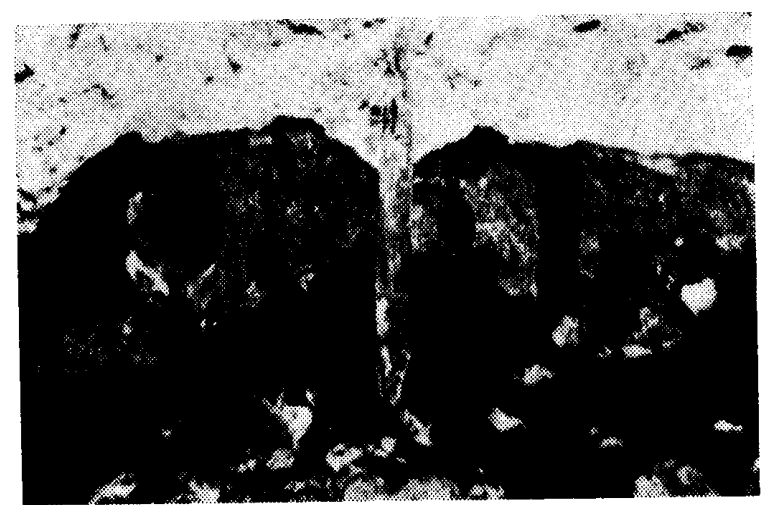

5 鉄 筋 膨 張・鉄 骨 浮 錆

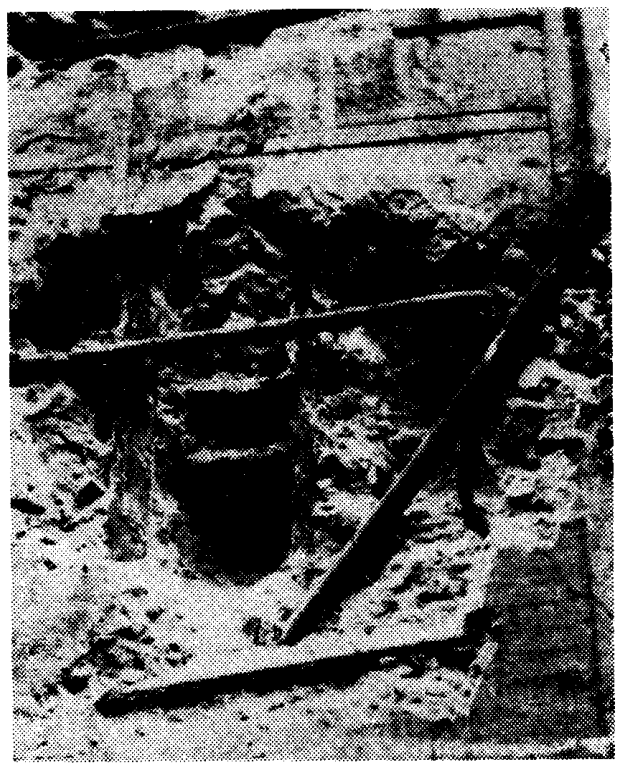

61 の処所ると……

実験式と比較する。調查絬果と注注一致する。即ち， $t=7.3 x^{2}, x=16.6$ 粍, 第 1 表普通面の平均深さ 17 粍

○打継面の中性化は普通面より超かに深く, 鉄筋の付 着力が多くは失われている。またすべての打継面直上部 


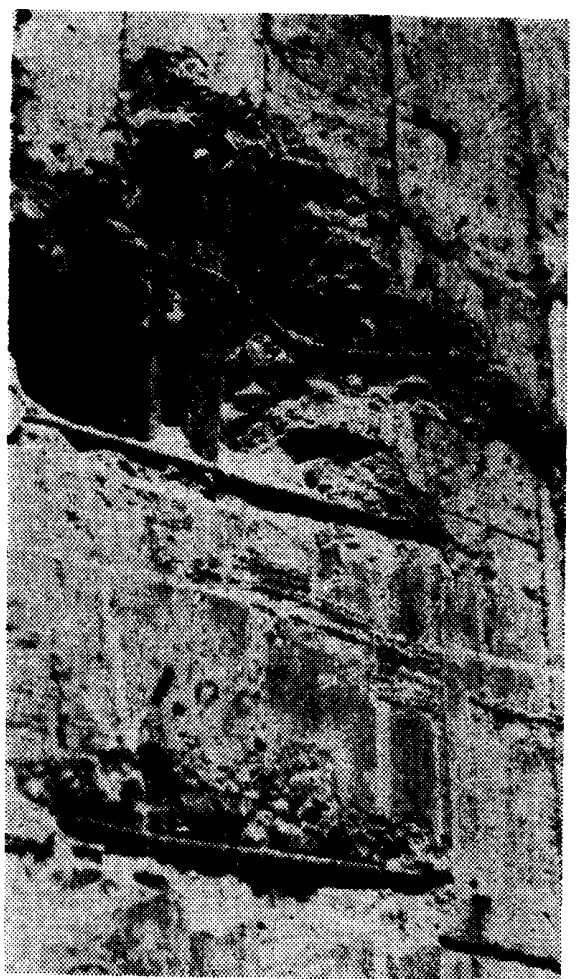

7 打継直上部材料分離
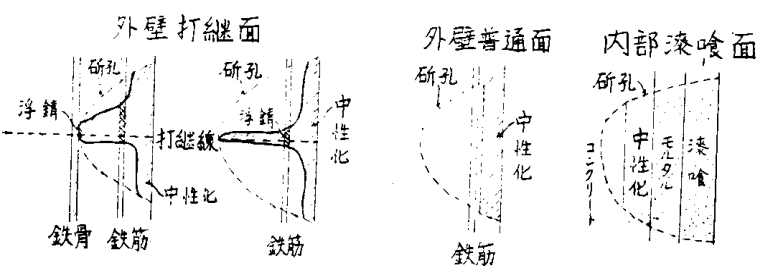

第 1 図

が直下部より大きく深く中性化している。これはコンク リート材料の分離が直上部に多いためで, 岸谷博士の実 験結果と若干趣きを異にする結果となった。

一普通面の中性化は高所が早く低所が遅い。（5階平 均 21 粍 1 階平均 14 粍）また大通りに面して開けた東 面と，これに近い東南部分が早く，中庭や遮へい物江面 する部分は遅い。雨風，排気ガス，㙁分を含んだ空気の 何れの影響が強かったか不明であるが少くとも㙁分は除

第 1 表 中性化進度比較表 (1)

\begin{tabular}{|c|c|c|c|c|c|c|c|}
\hline \multicolumn{8}{|c|}{ ○普通面（打継面以外の壁面）（個数）は試験個処数示示 } \\
\hline 方位 & 位置 & 階数 & 中性化深 & \&(耗 & & 個数 & 状況（鉄部及びコンクリート） \\
\hline \multirow[t]{4}{*}{ 東 } & 百; 南寄り & 5 & $27 \sim 32=$ & 平均 3 & & 3 & 鉄筋浮錆酸化・龟裂 \\
\hline & " & 1 & $12 \sim 33$ & $" 2$ & 3 & 2 & 鉄筋膨張 \\
\hline & 北寄り & 5 & & & & 2 & 亀裂 \\
\hline & " & 1 & $22 \sim 26$ & $\Rightarrow 2$ & & 2 & 鉄筋酸化 \\
\hline \multirow[t]{3}{*}{ 西 } & 南寄り & 5 & $12 \sim 15$ & $" 1$ & & 3 & 鉄筋異状なし \\
\hline & " & 1 & $5 \sim 15$ & $" 1$ & & 2 & 鉄筋酸化 \\
\hline & 北寄》 & 5 & $23 \sim 25$ & $" 2$ & & 2 & $"$ \\
\hline$"$ & $"$ & 1 & $5 \sim 10$ & & 8 & 2 & " \\
\hline \multirow{2}{*}{ 南 } & 東奇门 & 5 & $23 \sim 26$ & 2 & & 2 & 鉄筋鉄骨酸化 \\
\hline & $"$ & 1 & $18 \sim 21$ & 2 & 0 & 2 & 鉄筋浮錆, 鉄骨酸化 \\
\hline$"$ & 西寄 : & 1 & $5 \sim 10$ & & 8 & 2 & \\
\hline 北 面 & 東寄 & 1 & & 1 & & 1 & " \\
\hline & 西寄） & 1 & $7 \sim 8$ & & 8 & 2 & 鉄筋浮錆 \\
\hline \multirow{2}{*}{ 中庭 } & & 5 & $10 \sim 16$ & 1 & & 3 & 鉄筋酸化 \\
\hline & & 1 & $8 \sim 12$ & 1 & & 2 & " \\
\hline \multicolumn{3}{|c|}{ 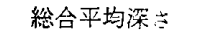 } & & 1 & & & \\
\hline
\end{tabular}

第 1 表 中性化進度比較表 (2)

\begin{tabular}{|c|c|c|c|c|c|}
\hline \multicolumn{6}{|c|}{ ○打継面（個数）は試験個処数を示す } \\
\hline 方向 & 位置 & \multicolumn{2}{|c|}{ |階数|中性化深さ } & |個数 $\mid$ & 状況（鉄部及びコンクリート） \\
\hline 東 面 & 南笴り & 5 & $55 \sim 80$ 平均 66 & 3 & 鉄筋 $19 \phi$ 等浮錆 \\
\hline " & " & 1 & $25 \sim 70 \% 50$ & 3 & " $22 \phi$ 膨張, 上部材料分䌖 \\
\hline 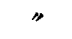 & 北笴り & 1 & $40 \sim 70 " 55$ & 2 & " $19 \phi$ 断面減少，材料分離 \\
\hline 南 面 & 東寄り & 1 & $50 \sim 95 \Rightarrow 75$ & 4 & " 浮錆,鉄骨酸化，材料分離 \\
\hline 北 面 & 西寄り & 1 & $51 \sim 102 " 77$ & 2 & 鉄筋鉄骨浮錆，材料分離 \\
\hline \multicolumn{3}{|c|}{ 総合平均深さ } & 65 & & \\
\hline \multicolumn{6}{|c|}{ ○室内面（中性化深さはそれそれ浗喰厚等を含む） } \\
\hline \multirow{2}{*}{\multicolumn{3}{|c|}{ 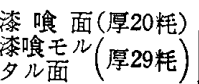 }} & $36 \sim 45$ 平均 38 & 6 & 渿喰啟アルカリ \\
\hline & & & $34 \sim 50 \Rightarrow 40$ & 7 & モルタルアルカリ性 \\
\hline
\end{tabular}

外して考えてよいようである。理由は後述空枠の項で東 面の空势が特に塩分の影響をうけた様にみえないから。

-一般に室内面の中性化は外壁普通面上り早い。

\section{3 雨漏之耐弾層に関する調查}

（1）概要, 調查目的, 要領 昭 15 . 完成した屋根 クリンカータイル仕上面の上に昭 19. 全面的に耐弾層 を設けたが，室内及び頂部外壁内外面への雨漏がやま ず，屋根の部分的補修で洨効果がなかった。これに関連 して当時「外壁が老朽化した今日耐弾層を残して耐震的 に安全か，撤去しなければ雨漏がやまぬか，そのままに して完全な外装工事ができるか，後からタイルが剥離せ

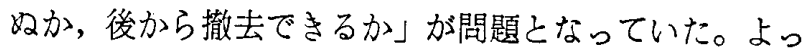
て昭 34.2 耐弾層の存在による外壁への漏水を観察し, 近く実施のタイル貼外装に及ぼす障害について考察し た。

（2）調查結果・耐弾層は 40 45 糎厚の $\mathrm{R} \mathrm{C}$ 造，鉄 筋は上面綎横 $22 \phi-160$ マ下面 $25 \phi-180$ マ, 餅網状の 2 面を $12 \phi-160$ マで稻妻型に緊結し，各継手を溶接， 爆弾の侵徹と衝撃による層の分離を防いだもので，コン クリートは上下 2 度に打ってある。滞溜水の状況は任 意に斫った耐弾層 4 力所のうち, 半数は上面汃ら 10 粗 下が水浸しであった。 ・漏水の原因は新築時耐弾層を予 期しなかったのでアスファルト防水のパラペット部立上. りが不足したとと，耐弾層に水勾配が全然なく水溜りを 生ずるてと等から，パラペットやペントハウス壁との取 合部分から雨水が浸透滞溜し，弱点から洩れるためであ

る。・漏水状況は，室 内や階段には長年の漏 水により遊離石圧が累 積，外壁へは概して頂 部に近い打継面（屋根 防水層の高さ）加ら渗 出しており，その量は 雨上り後一定時間を経 てみるみる増加し数日 間湿る。

(3) 考察 以上の

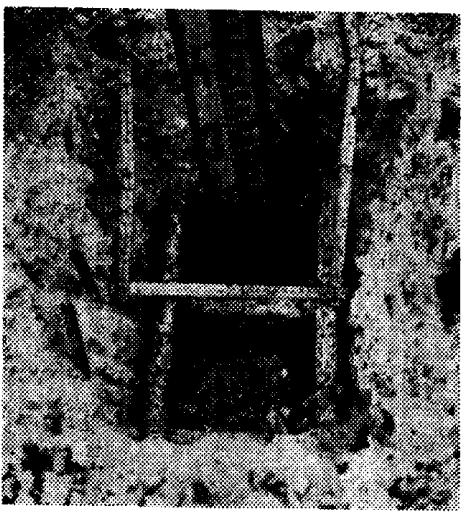

8 耐弾層・カリンカータイルが みえる 


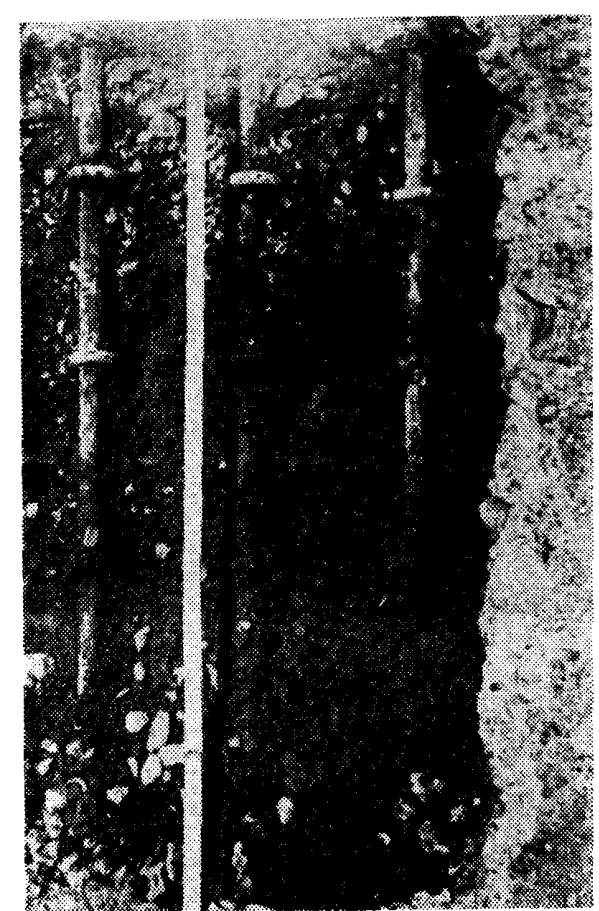

9 耐弾層滞水状況 10 糎所り下げた処

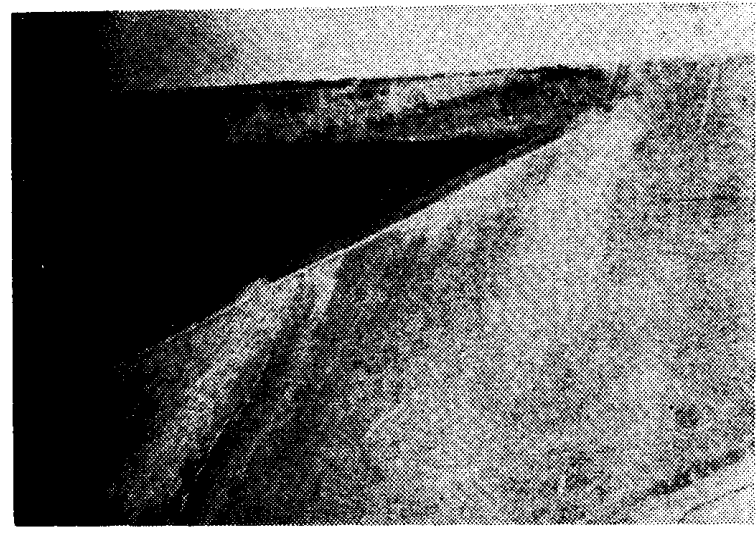

10 階段附近・遊離石灰累積の状況

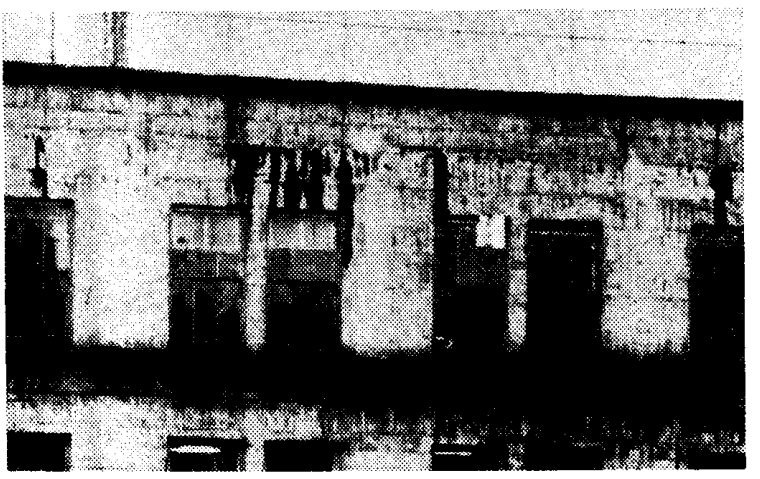

11 雨水の外壁への渗出状況 (1)

結果から酎弾層を残してタイルを貼れば次の障害が起 り，㳯物の弦度と酎久性を維持する上から困難が予测さ れる。工專中の漏水により，タイル附着不光分とな り，完成後は夕イル重の水の水結により剥離が起る。 遊離石灰により外装が污染される。外装のためコンク リート母体やタイル裏の水が乾燥せず，内部鉄材や空枠 を窝蝕させ，構造耐力を弱劣。

耐弾層を外装後に撤去すれば衝撃がタイルに悪影響を 及活し，新防水層を酎弾層の上に設ければ荷重が累加さ れる等困難な問題が多い。

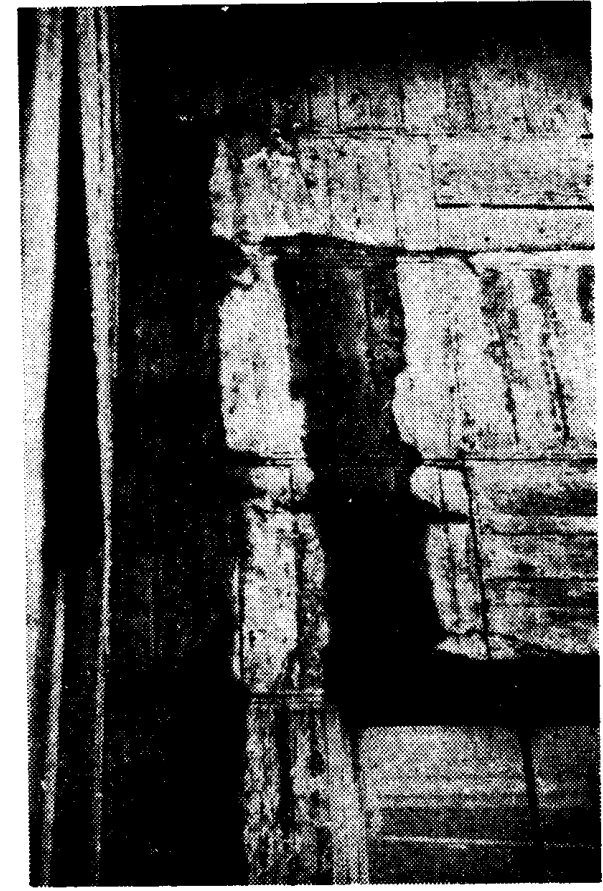

12 雨水の外壁への渗出状況 (2)

4 耐弾層設置工事の当時の関係者の意見

昭 34.5 戦時，主任技師だった会計模查院某局長に 今までの調査資料を呈示して意見を伺った。。要旨は 過去に，建物の命数を保つためタイル貼を主張し諸々の ことを懸念したが，今回再び貼ることとなり，同じ問題 がおきたかけである。当院の使用している文部少庁舎も 耐弾層をもち，雨漏とタイル剥離が続いている。貴庁合 の場台屋根をこのままタイルを貼机岕，剥離することは 明らふで防水范考光るべきだ。上に新防水層を設けても 一旦下部に溜った水は上をふさがれ，更に土中の水と同 一現象を呈して脱水さず，鉄部を腐蝕させる。目にみえ る外壁や柱よりもアスファルト老化部分から下への浸水 を受ける恐れのある梁やスラブ，特に大梁やその端部の 構造耐力に不安がある。

\section{5 他庁舎における耐弾層の現状とその影響}

昭 34.6 他庁含の状況調查をした。何れも耐弾層の ため保全上悪影響をうけており，間題はタイル剥離と耐 震上の色険に二分される。

一文部省庁舎 室内外への雨漏, 外装夕イル剥離, 害 枠の简蝕が多く, 数年前酎弾首上に防水モルタルが施さ れたが効果が少ない。戦火をうけない中庭面外装の剥離 も多く，全体的に最もひどく，耐弾層撤去は衝揧により タイル剥離を促すとみうけられる。

○人事院ビル 雨漏, タイル剥離は少く遊離石灰によ る外萃污染程度で最も被害が少い。原因は建物幅即ち受 水面積最少，水勾配が充分にあること等が考方られる。

○警視庁庁舎 被害は少い。耐弾層設置のテストケー スとして人念に施工され，充分水勾配をとり，表面にア スファルトを塗布した等のためと思われる。タイルと外 装人研が若干浮いており，乙の庁舎はガラスに㞮裂が入 るとすぐ入替られるのでよくわかるのだが, 微震軽震の 
都度ガラスが割れ，その際人研が剥落したことがある。 重量物載荷による層間変位によるものであれば危険であ ると感じて，担当者は耐弾鼍の撤去を決意している。

\section{6 空枠の腐蝕状況の調查}

この建物の空枠は上下枠, 堅枠内外, 四板共 2.0 粍厚 の良質のもので，20 年䦓殆んど補修されていない。空 名り外装末完成で屋根から外壁コンクリート母体に水が 入るといった環境にあり，枠の腐蝕膨張歪等がみられ る。なお外装の未完成は枠の保全にマイナスとなったか 否か不明であるが，昭 37.6 全面的調査を行った。痛 み方を次のように分類する。

$\mathrm{a}$ 級 全部の取替を要す

b " 皿板全部, 堅枠下部 30 糎切断取替を要す

c " 皿板堅枠共穴埋補修を要す

d”歪なおし特に水切部の歪なおしを要す

敷地が傾斜しているため地 1 階共ドライエリヤ的なも のをもち，湿気に対する条件はにている。地〜 5 階別及 び日照通風の良否にわけて痛み方を詨比してみる。なお わるい処亡は中庭入隅で地面に近く，近接して通風を奶 げるもののある処または類似の場所とする。

第 3 表 サッシの痛み方対照表

\begin{tabular}{|c|c|c|c|c|c|c|c|c|c|c|c|c|}
\hline \multirow{2}{*}{ 分類 } & \multirow{2}{*}{$\begin{array}{l}\text { 地階 } \\
(ケ)\end{array}$} & \multirow{2}{*}{$\begin{array}{c}1 \text { 階 } \\
(\zeta)\end{array}$} & \multirow[t]{2}{*}{2} & \multirow[t]{2}{*}{3} & \multirow[t]{2}{*}{4} & \multirow[t]{2}{*}{5} & \multirow{2}{*}{ 屋階 } & \multirow{2}{*}{ 計 } & \multirow{2}{*}{$\mid \begin{array}{l}\text { 日照通 } \\
\text { 風なき } \\
\text { 処 }\end{array}$} & \multicolumn{3}{|c|}{$\begin{array}{l}\text { 七趡のして部 } \\
\end{array}$} \\
\hline & & & & & & & & & & \begin{tabular}{l|} 
一般 \\
個処
\end{tabular} & 屋階 & 計 \\
\hline a & 2 & 3 & 0 & 0 & 0 & 0 & 0 & 5 & 3 & 2 & 0 & 5 \\
\hline b & 1 & 9 & 1 & 2 & 1 & 0 & 2 & 16 & 11 & 3 & 2 & 16 \\
\hline c & 0 & 2 & 5 & 0 & 1 & 0 & 1 & 9 & 3 & 5 & 1 & 9 \\
\hline d & 16 & 53 & 6 & 1 & 0 & 0 & 2 & 78 & 60 & 16 & 2 & 78 \\
\hline 計 & 19 & 67 & 12 & 3 & 2 & 0 & 5 & 108 & 77 & 26 & 5 & 108 \\
\hline 空総数| & 169 & 421 & 418 & 411 & 476 & 324 & 24 & 2,243 & 228 & 1,991 & 24 & 2,243 \\
\hline 補修率|1 & $1.2 \%$ & $.9 \%$ & $2.9 \%$ & $0.7 \%$ & $0.4 \%$ & 0 & $20.8 \%$ & $4.8 \%$ & $33.8 \%$ & $1.3 \%$ & $20.8 \%$ & $4.8 \%$ \\
\hline
\end{tabular}
された。

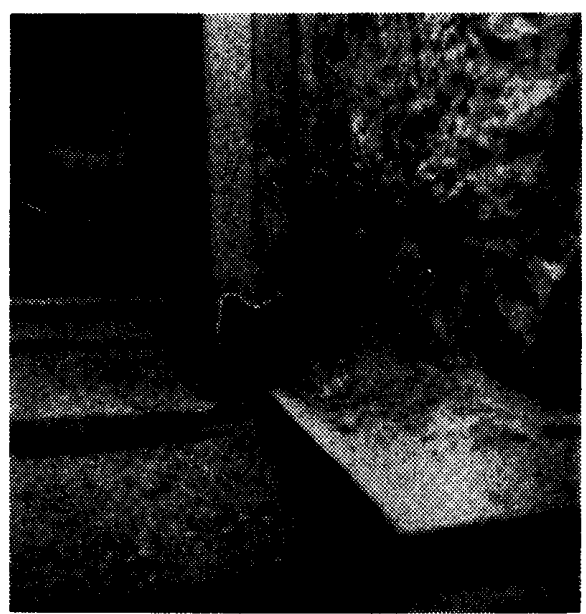

14 空 枠 腐 蝕 状 況

行われないとと，屋上面に対する空と, 地面に対する 1 階空の相対的環境がにているとと等が考えられる。

\section{7 耐弾層荷重よ建物耐力に関する考察}

（1）耐弾㬝荷重 $1 \mathrm{t} / \mathrm{m}^{2}$ は設計外のもので，設置当 時, 層自体で自重を支えて，屋根スラブではなく直接柱 にかかるものとして検討がなされ，柱と基礎は大丈夫と

（2）構造体は鉄骨でもたせ，鉄筋は単にコンクリー トを鉄骨に附着させるために使用されたと聞 いているが, 外壁中に $25,22 \phi$ 筋があり, 戦 前の構造図と計算書が紛失していて確めよう がない。

（3）新築当時の設計条件は震度 0.1, コ ンクリートと鋼材の許容強度は長短期の別な く $40 \mathrm{~kg} / \mathrm{cm}^{2}, 1,400 \mathrm{~kg} / \mathrm{cm}^{2}$ であった。

（4）外壁の鉄筋は打継部で殆んど附着力 を失っている。

（5）建設担当機関における最近の検討では, 地震耐 力は (4) のために 84\% に低下, 而弾層載荷により総合 して 72\% に低下したとされた。

（6）大梁に及ぼす耐弾層の暁みによる力，梁の痛み 方の程度等まだ不明の点もある。昭 $32.9 \sim 34.7$ の間 以上の諸事項の調查検討を行ったが, 総合して「耐震上 撤去が望ましい」とされた。

\section{8 外壁補修とタイル貼工事の方法に関する協議}

昭 36.5 建設, 研究, 保守各担当機関が集り協議し た。その要旨は次のとおり。

・老化した建物ではあるが耐弾層が撤去されるの で，工事に際して構造補強はあまり必要ではない。

- 外装タイルは薄くて軽いものがよいが, 小口程度 でないと貧弱である。在来外壁への附着が問題である が，実験して調べる。

- タイル貼工事の時期については異論があったが， 「特定季節に限定しない」こととする。

- 外壁補修については, 亀裂を生じた処のみかきと 
り他は鉄錆流出があってもそのままとする。但し打継面 はかきとる。

- 建物の耐久性については，文部省や人事院の庁舎 程度に存続させたいが，難しい問題が多い。

\section{9 工事の状況及び結果}

昭 35.2 武験的に一部而弾首を撤去, その結果能率 の点から破砕機でコンクリートを斫り，電気で鉄筋を溶 断し，騒音と震動をさけて夜間作業とすることに方針が 決定した。昭 36.6 関係機関打合せの結果撤去は耐弾 層のみとし，在来クリンカータイル以下は残され，上に 新防水層を設けた。老化した旧防水層取替の時の漏水々 在来スラブ損傷を恐れて新防水層による荷重累加の不利 を忍んだ。外装工事は主に夜間行われ，中性化し吸水率 が大きくもろくなったコンクリート粗噤面にタイルを貼 るととに特に苦心が払われたようである。目荒しを行 い，アクリル酸エステル重合体を主とする接着剤混入モ ルタルが下中塗りされたが，昭 37.12〜38.1 の間異状 乾燥と寒波にあい，下地モルタルの乾燥収縮に上る龟裂 と，在来壁からの剥離が一部に起り，工事が中断され た。よって一部をかき落し残部に，実験による確信にも とづき $1 \mathrm{~m}^{2}$ 当り 1 本のドライヴィットを打込み止金を つけて，モルタルを在来壁に之めつけ，爾後の工事はモ ルタル厚をうんと減じてタル貼が完成された。

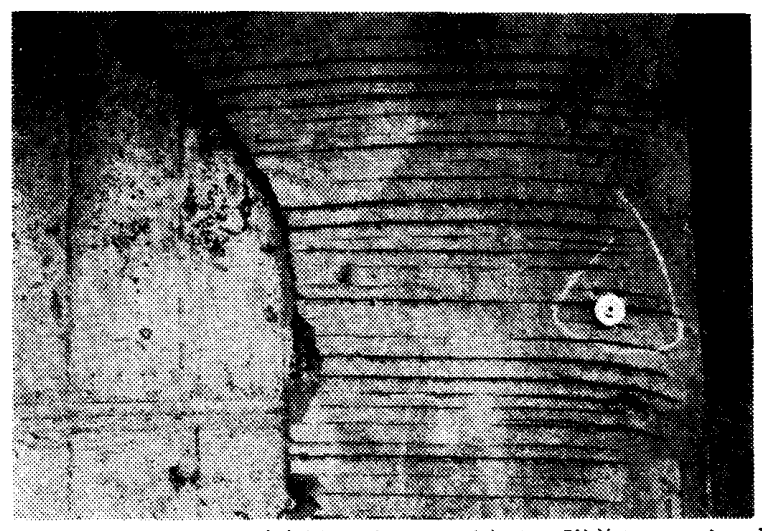

15 下地モルタル不良個所かきとり（克分汇附着していない）

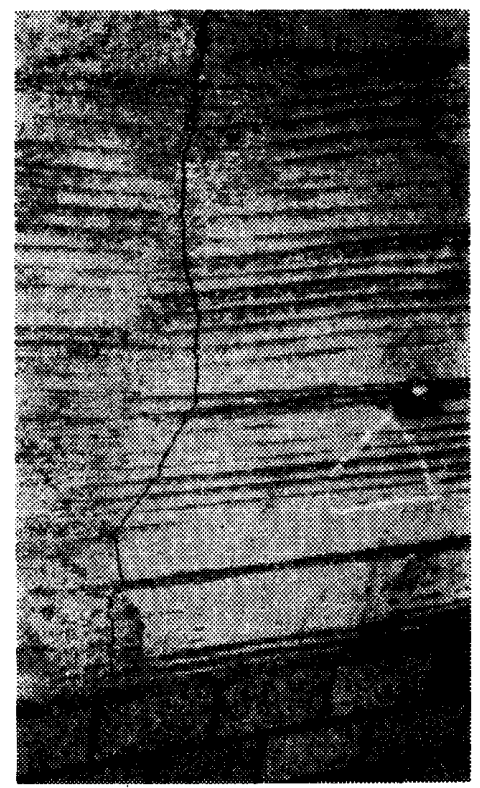

16 下地乾燥収縮亀裂

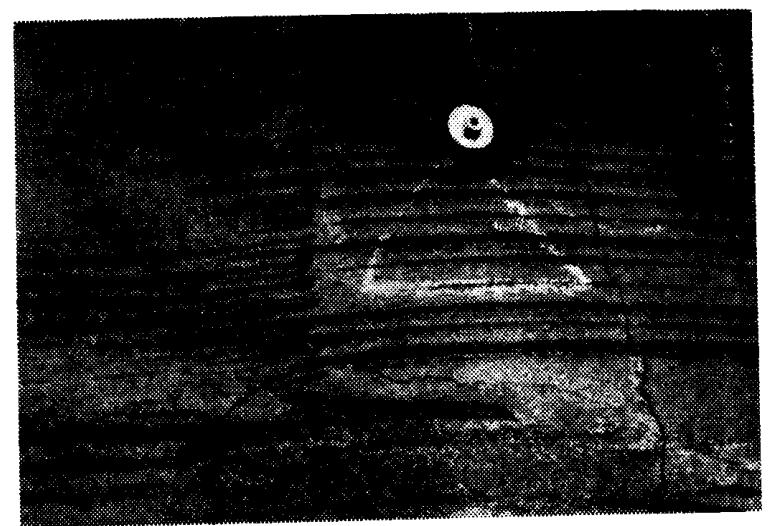

17 下地モルタル乾燥収縮亀裂（ドライヴィットでとめつけ）

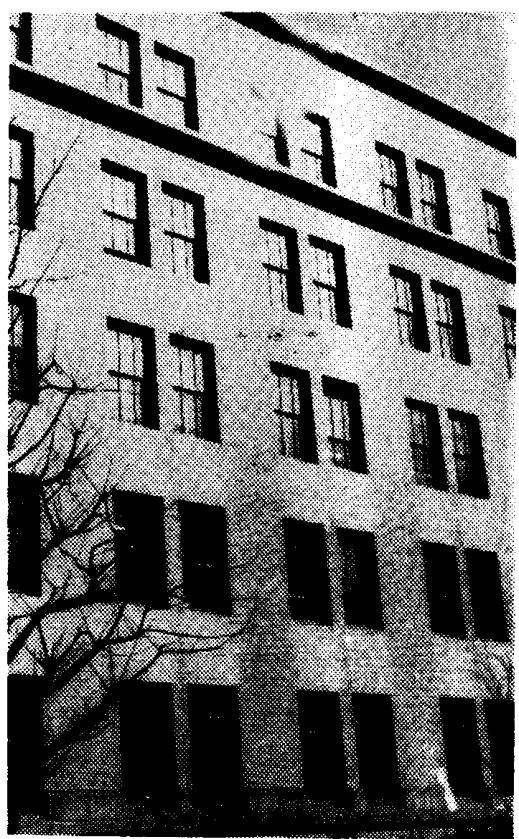

18 タイル外装完了

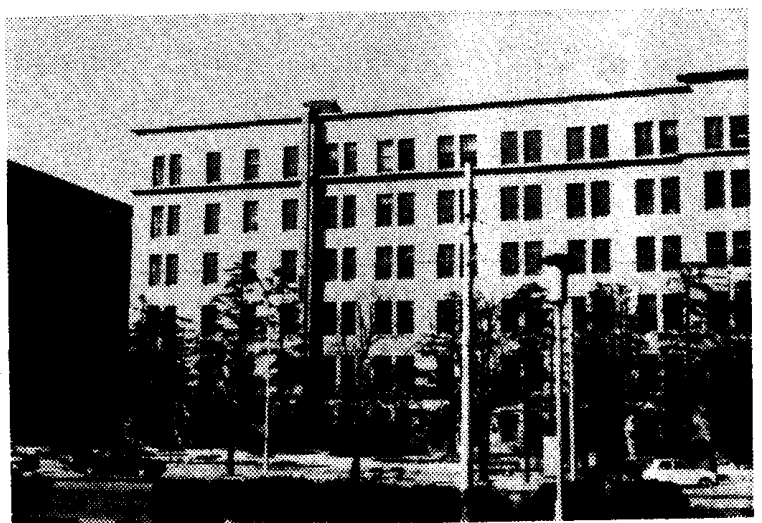

19 タイル外装完了

所感 以上の経緯をへてこの建物は一応回復した。こ れからはその保全が問題である。一般に建物の保全に関 しては，外壁コンクリート打継面，㤎迴り及び被覆のう すい個処の鉄筋の防錆々，外壁頂部一の雨䨕防止処理が 特に重要である。ここでは雨漏の主因を耐弾層の存在に 求めたが，耐弾層のない薄物でも屋上附近から外壁頂部 へ雨漏のみられる処が多い。この辺の処理も併せて重要 であると痛感する次第である。

附記 調查全体化わたり大藏技官小関保真君の有益な助 力をえた。感謝します。

文献 1）岸谷博士：鉄筋コンクリートの耐久性 